\title{
Ritos digitais, táticas e finitude: Confrontando a morte no Facebook
}

\section{Carlos Affonso Mello}

Mestre em Comunicação Social pela Pontifícia Universidade Católica do Rio de Janeiro. Graduado em Didática de Ensino Superior pela mesma instituição. Graduado em Comunicação Social pela Faculdades Integradas Hélio Alonso (Facha), com habilitações em Jornalismo \& Relações Públicas e Publicidade \& Propaganda.

E-mail: loscar.affonso@gmail.com

\footnotetext{
* Trabalho apresentado no GT 3 Subjetividade e produção de sentido do VII Congresso de Estudantes de PósGraduação em Comunicação, na categoria pós-graduação. UFRJ, Rio de Janeiro, 15 a 17 de outubro de 2014.
}

Resumo: Expressão da sociedade global contemporânea, a tecnologia cada vez mais se apresenta como um fenômeno que coloca em questão a condição humana. A ambiência virtual é um local de novas trocas simbólicas e de atualização de tradicionais práticas humanas, como a comunicação. Nesse sentido, o presente trabalho tentará descrever e analisar o que estaria por trás de uma experiência cada vez mais comum nas páginas do Facebook, a saber, a de deixar mensagens e registros nos perfis de amigos e/ou conhecidos já falecidos. Pretendemos demonstrar que esse tipo de comportamento pode ser compreendido não somente como resultado de um trabalho de luto, mas também como uma subversão do princípio utilitário de uma rede social digital, pensada enquanto uma ferramenta de comunicação.

Palavras-chave: Subjetividade; Representação; Tecnologia; Narrativa; Ritos fúnebres.

\section{Digital rites, tactics and finitude: Facing death on Facebook}

Abstract: Expression of contemporary global society, technology is presented as a phenomenon which put the human condition into question. Virtual ambience is a place of new symbolic exchanges and upgrade traditional human practices, such as communication. In this sense, this paper attempts to describe and analyze what is behind an increasingly common experience on Facebook pages, namely to leave messages at the profiles of friends and/or acquaintances deceased. We intend to demonstrate that such behavior can be understood not only as a result of a work of mourning, but also as a subversion of the principle of utility of a digital social network, conceived as a communication tool.

Keywords: Subjectivity; Representation; Technology; Narrative; Funeral rites. 


\section{Introdução}

Expressão da sociedade global contemporânea, a tecnologia cada vez mais se apresenta como um fenômeno que estimula, muito além do surgimento de novos arranjos sociais, culturais, políticos e econômicos, a própria condição humana. A integração de computadores portáteis, aparelhos de celular e uma gama de outros dispositivos digitais ao dia-a-dia dos indivíduos, vem modificando o espaço público e privado. A ambiência virtual passa a ser um local de novas trocas simbólicas, um terreno profícuo para o surgimento de correlatos processos de subjetivação, mas também de atualização de tradicionais práticas humanas, como a comunicação.

A convivência com esses suportes, sua naturalização na vida cotidiana, seus usos nos atos mais inconscientes do comunicar, modifica a cognição, a maneira como se sente, percebe, conhece e, por conseguinte, se é no mundo. A reconfiguração de dimensões societais clássicas (SODRÉ, 2001: 18-35), como escola e família, articuladas a meios ultramodernos de midiatização (rádio, televisão e, mais recente e fortemente, a Internet), são acontecimentos hodiernos, frutos diretos do impacto dessas tecnologias na vida humana - convergência de momentos ontológicos que formam e conformam sujeitos.

Dentre os muitos exemplos de aplicação dessas tecnologias recentes, podemos destacar um que parece ocupar um lugar cada vez mais central: as redes sociais. Aparelhos de telefonia móvel, por exemplo, aparentemente já exercem uma função protética, isto é, atuam como extensões do corpo e da consciência. Integrados a redes sociais como o Facebook ou o LinkedIn, os smartphones potencializam não somente o que Deleuze chamava de formas ultrarrápidas de controle ao ar livre (DELEUZE, 2010: 224), mas também o indivíduo enquanto eixo tecnointerativo dessas redes, enquanto agente ativo de construção de discursos.

${ }^{1}$ COMPUTERWORLD. Brasil fecha agosto com 114 milhões de acesso banda larga. Disponível em:

http://computerworld.com.br/telecom/2 013/09/30/brasil-fecha-agosto-com-114milhoes-de-acesso-banda-larga

${ }^{2}$ GIZMODO. Facebook ultrapassa 1 bilhão de usuários no celular e tablet. Disponível em:

http://gizmodo.uol.com.br/facebook1q2014/
Levantamentos recentes ${ }^{1}$ mostram que somente o Brasil contabiliza 114 milhões de acessos à banda larga, sendo 93,2 milhões provenientes de conexões móveis e os demais de acessos fixos - no mundo todo, usuários ativos do Facebook já somam mais de 1 bilhão ${ }^{2}$. Dados como esses se mostram relevantes por deixar explícita a relação de intimidade que vem se estabelecendo entre as pessoas e esses dispositivos de comunicação. Ainda que o efeito dessas tecnologias não seja diretamente percebido por comunidades aqui ou acolá, podemos partir da premissa de que o surgimento de quaisquer inovações tecnológicas interpela $\circ$ mundo também daqueles que não se servem diretamente dessa tecnologia (MACHADO, 2010: 22.), especialmente no contexto da globalização.

Nesse sentido, não seria exagero algum reconhecer que o Facebook, como grande parte das produções encontradas na Internet, segue uma lógica econômica, isto é, que enquanto produto está adequado à lógica de mercado. Logo, é destinado ao consumo, sendo uma empresa com capital aberto, investidores, operações financeiras que dependem diretamente dos humores das bolsas e de seus consumidores - os usuários. Obviamente, como bem observou Morin em Cultura de massas no século XX, boa parte do sucesso desse mercado, como de qualquer outro, se deve à aptidão de alcançar o lucro, à voracidade de seus métodos e às condições inerentes ao sistema capitalista.

Especificamente no caso do Facebook, os indivíduos (usuários, consumidores) são inseridos em um conjunto articulado e integrado de relações bem planejadas, ou seja, ao consumir seu produto, navegar e interagir nas redes, o fazem segundo as regras. São regras de um jogo que tem como pano de fundo códigos próprios, amarras digitais binárias, interfaces virtualizantes e premissas da indústria 
espetacular do entretenimento. De outro modo, podemos dizer que os usuários são inevitavelmente impelidos a responder nos termos de funcionamento dessas ferramentas, i. e., segundo a lógica de programação (e de mercado) sobre a qual estas foram erigidas.

Enquanto redes sociais na Internet, essas ferramentas funcionam como dispositivos exemplares, em que podemos observar a crescente tecnologização da cultura (FELINTO, 2005: 46). Ao ampliar as experiências da realidade tradicional, o Facebook torna-se lugar para onde convergem as mais variadas práticas humanas e toda sua complexa e vasta gama de operações comunicacionais. Relacionamentos, afetividades, discussões políticas e outras inúmeras atividades que caracterizam o humano, tais como experiências de fruição artística, ganham novas dimensões, alimentando nesse processo o princípio dessas ferramentas, e fornecendo o substrato, os registros e os dados interacionais tão valiosos para seu funcionamento.

Diante disso, percebe-se que os fluxos comunicacionais dos usuários dessas redes, entre si e em relação aos responsáveis pela produção dessas ferramentas, em algumas ocasiões, fazem com que os papéis de produtor e consumidor se misturem. Vale lembrar que, distantes da concepção frankfurtiana da recepção passiva, as teorias da recepção já apontavam para uma realidade onde o receptor não é mera etapa final dentro de uma cadeia produtiva, mas exerce ativamente sua função dentro desta, ao codificar e decodificar os sinais, as mensagens, os signos fornecidos pela indústria cultural.

Obviamente tal relação de retroalimentação, longe de ser marcada por um equilíbrio entre ambas as partes (usuários e redes sociais), não é suficiente para alterar a realidade desse mercado e muito menos os papéis de produtor e consumidor de maneira radical. Entretanto, há que se notar que no que tange as produções oriundas da Internet o poder de decisão conferido aos usuários, que hoje são também encarados enquanto produtores de informação, aparentemente, flexibiliza um pouco mais essas relações. A possibilidade de interagir com a produção que se consome se amplia.

O pensador francês Michel de Certeau é um dos que acreditava na capacidade inventiva, intelectualmente combativa e criativa do ser humano, em especial ao que chamava de homem ordinário (CERTEAU, 2011: 55). Para este pensador, toda e qualquer ação, quando calculada e direcionada pelo segmento de produção ao mercado consumidor, deixa sempre brechas, espaços não contemplados ou previstos pela estratégia marcadamente impositiva da economia, o que por sua vez propicia o surgimento de modos de usos, consumos, fazeres e manipulações particulares, operados por esses mesmos consumidores.

Dentro dessa lógica, o presente trabalho tentará analisar e descrever um uso bastante particular, um modo um tanto quanto curioso de se manusear a ferramenta de comunicação mais espetacular do momento: o Facebook. Que uso seria esse? Uma prática cada vez mais comum de usuários (consumidores) que, durante algum tempo, seguem mantendo "contato", deixando mensagens e registros dos mais variados tipos nos perfis de amigos e/ou conhecidos já falecidos.

Partindo da hipótese de que esse uso se dá numa esfera subjetiva, onde a ausência de um ente querido molda um cenário caótico de uma perda irreversível, pretendemos mostrar que esse tipo de comportamento pode ser compreendido não somente como resultado de um trabalho de luto, mas como uma subversão do princípio utilitário de uma rede social digital, pensada enquanto uma ferramenta de comunicação. Da mesma forma, buscaremos 
3 UOL TECNOLOGIA. Facebook tem 1,23 bilhão de usuários mundiais; 61,2 milhões são do Brasil. Disponível em: http://tecnologia.uol.com.br/noticias/af p/2014/02/03/facebook-emnumeros.htm

\footnotetext{
${ }^{4}$ Disponível em:
}

https://www.facebook.com/facebook fundamentar essa leitura, entre outros, à luz do pensamento de Certeau, por julgar que este fornece uma abordagem criativa e que valoriza a autonomia criadora dos usuários e consumidores.

\section{Facebook: rede social digital, ferramenta de comunicação, dispositivo}

Lançado em fevereiro de 2004 o Facebook, serviço de rede social idealizado pelo americano Mark Zuckerberg e pelo brasileiro Eduardo Saverin, hoje conta com mais de um bilhão de usuários em todo o mundo - somente no Brasil, terceiro lugar no ranking de contas ativas, somam-se mais de 60 milhões $^{3}$. O Facebook "celebra como nossos amigos nos inspiram, nos apoiam e nos ajudam a descobrir o mundo quando nos conectamos"4. Mas não só isso: a rede social também é lugar disputado pelos mercados mais variados, possibilitando a criação de conexões das mais diversas entre quem produz e quem consome.

É raro encontrar um produto, seja ele um macarrão instantâneo ou um equipamento de som, que não disponibilize o endereço da página do Facebook de seu fabricante na sua embalagem. Além dos tradicionais meios, como serviços de atendimento ao consumidor e sites, as empresas hoje mantêm dinâmicos canais de comunicação com seus clientes através de suas contas no Facebook. Tal qual uma rede social da realidade física, a criação de Zuckerberg e Saverin consegue simular práticas humanas complexas em um ambiente virtual, em consonância com a lógica do recente "fenômeno da estocagem de grandes volumes de dados e a sua rápida transmissão" (SODRÉ, 2002: 13).

(...) a abordagem da rede fornece ferramentas únicas para o estudo dos aspectos sociais do ciberespaço: permite estudar, por exemplo, a criação das estruturas sociais; suas dinâmicas, tais como a criação de capital social e sua manutenção, a emergência da cooperação e da competição; as funções das estruturas e as diferenças entre os variados grupos e seu impacto nos indivíduos (RECUERO, 2011: 20-21)

A chamada Comunicação Mediada por Computador (CMC) segue alterando as formas de organização e representação social, em todos os estratos de seu tecido. Ocorrendo em graus variados de interatividade, é nas redes sociais, em especial no Facebook, que a CMC apresenta seu mais alto grau de sofisticação e complexidade. Compartilhamento de fotos, vídeos, áudios, conversas em grupo e acesso a informações instantâneas são algumas das principais funções realizadas pelo serviço, que acumula uma concentração ímpar de dados de usuários (consumidores).

Assim sendo, a rede social em questão assume muitos dos atributos das já citadas formas ultrarrápidas de controle ao ar livre, uma vez que permite não só a utilização dos registros disponíveis em benefício pessoal de seus usuários controle da localização, da agenda, das atividades de terceiros -, mas serve de arcabouço informativo aos mercados. Estes podem aferir, muitas vezes de modo preciso, os gostos, as tendências, as ideologias, as afeições e as preferências de consumo de cada usuário, mediante o levantamento das pegadas digitais encontradas em seus perfis e respectivas interações.

O Facebook poderia, então, ser definido como um mecanismo, ou melhor, um dispositivo, se não de controle, ao menos de comunicação. A internet, os smartphones, a televisão, as câmeras de monitoramento são alguns exemplos de dispositivos contemporâneos. Utilizaremos aqui a concepção agambeana, moldada na esteira da filosofia de Michel Foucault, para definir um dispositivo, isto é, enquanto produto dos cruzamentos de relações de poder e saber, segundo um conjunto heterogêneo de elementos linguísticos e não-linguísticos, e que 
pode adotar uma função estratégica concreta numa relação de poder específica (AGAMBEN, 2009: 34/35).

(...) chamarei literalmente de dispositivo qualquer coisa que tenha de algum modo a capacidade de capturar, orientar, determinar, interceptar, modelar, controlar e assegurar os gestos, as condutas, as opiniões e os discursos dos seres viventes (...) um mesmo indivíduo, uma mesma substância, pode ser o lugar dos múltiplos processos de subjetivação: o usuário de telefones celulares, o navegador na internet, o escritor de contos, o apaixonado por tango, o nãoglobal etc. (AGAMBEN, 2009: 40)

A definição é abrangente, mas nem por isso menos interessante, ou adequada, já que o mecanismo ao qual se aplica possui também abrangência sobre diversos aspectos da vida humana. A abordagem dessa concepção também pode ser profícua por direcionar nossa percepção para a compreensão da relação, isto é, da proximidade teórica e prática existente entre as tecnologias e os dispositivos.

\section{Tecnologia: técnica, criação e tática}

A criatividade é uma característica humana que revela não só o óbvio, isto é, a disposição criadora, mas também um predicado que confere uma capacidade de resiliência sui generis da espécie. Através de suas habilidades físicas e intelectuais, mais do que agir para preservar seu habitat, o homem consegue adaptar-se a ambientes e situações adversas. Vivendo e reproduzindo-se em biomas que vão desde o calor dos desertos ao clima gélido de regiões polares, passando por zonas com temperaturas mais equilibradas e maior biodiversidade, os seres humanos são criaturas que se desenvolvem transformando o mundo ao seu redor. Diferentemente da grande maioria das espécies, que evoluem segundo as condições do meio como forma de sobreviver, o ser humano, de modo geral, consegue subverter esse padrão.

O homem não visa somente a sobrevivência. O homem visa sobre a vivência, isto é, sobre suas experiências cotidianas, sobre suas práticas corriqueiras, que mais do que garantir a preservação de um legado biológico também possibilitam o contínuo desenvolvimento da inteligência e da criatividade. Enquanto poiesis (do grego colocar, por, criar), esses atributos criadores, essas práticas "poéticas", permitem ao homem não somente performar sua predicabilidade adaptativa com êxito, mas fazer da vida um constante processo de criação. Mas o que criam os homens? Relações, significações, culturas, sociedades, conhecimento. E como criam os homens? Aplicando esse conhecimento, suas criações, ao consolidar algo que podemos chamar grosseiramente de técnica.

O filósofo alemão Martin Heidegger afirmava que "os gregos denominavam tanto a arte quanto o artesanato com a mesma palavra: techné; e, de maneira correspondente, o artesão e o artista com o termo techinités" (HEIDEGGER, 2007: 74). Nesse sentido, os verbos criar e reproduzir guardariam certa semelhança, já que as técnicas do artista e do artesão (e do "poeta") permitem tanto criar quanto reproduzir. O exercício constante de colocar em prática um conhecimento pautado em experiências prévias, confere ao homem sua habilidade de modificar o mundo e moldar sua realidade em benefício próprio. Não é necessário dizer, no entanto, que essa habilidade se dá com limitações, segundo condições adequadas e de naturezas diferentes - as efemérides ou as condições sociopolíticas, por exemplo.

Em uma sociedade industrializada como a contemporânea, em especial a ocidental, onde o capital especulativo é responsável pela dinâmica dos mercados em escala global, grande parte da capacidade criadora do homem é destinada à produção de elementos para o consumo. Raros são os casos onde esse potencial 
é completamente desvinculado da lógica do mercado. Mesmo as artes, hoje, são cooptadas pelos negócios, transformando-se em zonas muitas vezes tensas, como afirma Morin, entre as necessidades de segmentação de produtos e a demanda pela novidade; os pares antitéticos burocracia-invenção e padrãoindividualidade (MORIN, 2011: 16).

A concentração técnico-burocrática pesa universalmente sobre a produção cultural de massa. Donde a tendência à despersonalização da criação, à predominância da organização racional de produção (técnica, comercial, política) sobre a invenção, à desintegração do poder cultural. No entanto, essa tendência exigida pelo sistema industrial se choca com uma exigência radicalmente contrária, nascida da natureza própria do consumo cultural, que sempre reclama um produto individualizado, e sempre novo (MORIN, 2011: 15)

Michel de Certeau, por sua vez, busca valorizar o que ele chama de homem comum (ou homem ordinário, herói comum). Segundo o autor, trata-se de "narrar práticas comuns" (CERTEAU, 2011: 35), interrogar "sobre as operações dos usuários, supostamente entregues à passividade" (CERTEAU, 2011: 37). É fazer uma leitura do binômio produção-consumo, segundo uma perspectiva que leve em conta não somente as estratégias do mercado para objetivamente fazer circular sua produção e consequentemente seduzir seus consumidores. É privilegiar as "maneiras de empregar os produtos impostos por uma ordem econômica dominante" (CERTEAU, 2011: 39).

Esse homem comum é o homem do discurso humanista, que surge na aurora da modernidade. É o indivíduo, ser atomizado, que integra as massas. "Chamado 'Cada um' (nome que trai a ausência de nome), este anti-herói é também Ninguém" (CERTEAU, 2011: 58), argumenta Certeau. Apesar de figurar na construção discursiva das ciências da razão, esse ninguém nada diz sobre si mesmo, existindo no "teatro humanista" (CERTEAU, 2011: 58) apenas como um objeto a ser descrito, estudado e dissecado pelas disciplinas. O homem ordinário integra o povo, sobre quem se fala, mas a quem nunca é dada a oportunidade de falar.

Para o autor, existem fenômenos, manifestações, práticas e usos que surgem do cotidiano dessa massa anônima. São modos de fazer próprios que não provêm, ao menos num primeiro momento, das ações calculadas das esferas dominantes da economia. Dois tipos distintos de fazer cultural, então, marcariam a sociedade e organizariam seu espaço; as estratégias e as táticas. Ao primeiro corresponderiam as atividades de expansão da produção racionalizada, em outros termos, o sistema industrial, a lógica do mercado, o funcionamento das instituições, a cadeia de produção econômica, o pensamento tecnocrata. Sobre as estratégias, diz-nos Certeau:

Chamo de estratégia o cálculo (ou manipulação) das relações de forças que se torna possível a partir do momento em que um sujeito de querer e poder (uma empresa, um exército, uma cidade, uma instituição científica) pode ser isolado. (...) toda racionalização 'estratégica' procura em primeiro lugar distinguir de um 'ambiente' um 'próprio', isto é, o lugar do poder e do querer próprios (CERTEAU, 2011: 93)

A estratégia seria esse gesto calculado, cartesiano, encontrado na maneira como se constituem os campos "próprios", os lugares autônomos. Poderia ser definida como "um tipo específico de saber, aquele que sustenta e determina o poder de conquistar para si um lugar próprio" (CERTEAU, 2011: 94). As estratégias são lugares de discurso de poder totalizantes, de práticas de saber articulados e presentes em lugares propriamente físicos - "uma vitória do lugar sobre o tempo" (CERTEAU, 2011: 94). 
Em relação à estratégia, Certeau contrapõe o conceito de tática. Se aquela é organizada pelo forte, esta é a "arma" do fraco. Se aquela é afeita ao poder, esta não produz poder algum. Se àquela fala o "próprio", a esta fala o "outro". A tática é a maneira peculiar de fazer, de usar, de criar, segundo as ocasiões, de acordo com as oportunidades, dentro do campo do cotidiano e suas "mil maneiras de caça não autorizada" (CERTEAU, 2011: 98). A tática é realizada mediante o reemprego de produções e sistemas construídos longe desse cotidiano - uma vitória do tempo sobre o lugar.

(...) chamo tática a ação calculada que é determinada pela ausência de um próprio. Então nenhuma delimitação de fora the fornece a condição de autonomia. A tática não tem por lugar senão o do outro. (...) Ela opera golpe por golpe (...) O que ela ganha não se conserva. (...) Em suma, a tática é a arte do fraco (CERTEAU, 2011: 94-95)

As táticas, tanto quanto práticas calculadas, podem também ser encaradas como sedimentos ou legados de operações muitíssimo antigas, milenares. Nos termos de Certeau, são como "imemoriais inteligências, simulações, golpes de certos peixes, manobras de certas plantas" (CERTEAU, 2011: 46). São artifícios que a necessidade adaptativa colocaria como condição, permitindo a renovação, a surpresa, a superação de expectativas, a voz (e a vez) do "outro", dentro de um cenário aparentemente organizado, planejado, projetado segundo a perspectiva de um lugar de poder de um "próprio", i.e., diante o "próprio" de uma estratégia.

Táticas e estratégias, nesse sentido, não seriam práticas totalmente antagônicas, mas, antes, apresentariam certa complementariedade, porém, com uma pequena e importante diferença: as táticas não são previstas pelas estratégias, ao menos não em um primeiro momento, ou seja, não são seus subprodutos diretos, não são mensuráveis ou capturáveis de imediato pelos mecanismos tecnocráticos, mas aparecem como resultado indireto das imposições e das condições encontradas nesses campos.

\section{Rito digital: morte real, perfil imortal}

A era digital vem sendo saudada de maneira bastante diversa pela sociedade global - de modo mais ou menos exultante por parte alguns, de maneira mais ou menos crítica por outros. Independente dos enfoques e perspectivas, o certo é que as transformações impulsionadas pelo advento das tecnologias digitais e seus gadgets impactam todas as esferas da vida, sejam públicas ou privadas, coletivas ou individuais, institucionais ou familiares. São raríssimos os casos de pessoas que vivem de modo inteiramente independente de sua presença. Até mesmo em lugares remotos a tecnologia se faz sentir, como algumas comunidades distantes geograficamente de zonas urbanas.

A Internet é talvez o exemplo para onde convergem os mais variados tipos de produções digitais, o que a torna um lugar privilegiado para a análise do comportamento humano frente ao crescente desenvolvimento dessas novas tecnologias do imaginário (FELINTO, 2005: 47). A world wide web, rede mundial de computadores, ainda que utilizada estrategicamente pela indústria cultural, possui forte apelo à independência dos indivíduos, no que tange os processos criativos. Hipertextos, crowdsourcing e crowdfunding são algumas recémadquiridas engrenagens (conceitos) dessa realidade que seduz pessoas e descortina paisagens onde a criatividade permite a cada um ser o artesão, o técnico, o artista, o poeta de sua própria experiência criadora.

As aplicações dessas tecnologias são bastante distintas e se dão em intensidades diferentes. De textos a artigos publicáveis em blogs pessoais, até a gravação de composições musicais independentes da indústria fonográfica, o homem comum 
diversifica suas habilidades com um jogo tático. Michel de Certeau identifica a bricolagem e a sucata como exemplos desses "gestos hábeis do 'fraco' na ordem estabelecida pelo 'forte', arte de dar golpes no campo do outro, astúcia de caçadores" (CERTEAU, 2011: 98). Em certa medida, é isso o que se reforça com essas novas tecnologias, passíveis de manipulação por parte dos usuários, operadas como forma de reagir, readequar, reconduzir ou reorganizar uma vivência pessoal, cotidiana.

Nesse sentido, retomando a especificidade da rede social Facebook, um comportamento um tanto quanto curioso de muitos usuários merece menção. De maneira híbrida, parecendo mesclar tradições seculares com as atualizações constantes promovidas pelos desdobramentos das tecnologias contemporâneas, um número cada vez maior de usuários passa a ser ver diante da possibilidade de deixar mensagens nos perfis de seus familiares, amigos ou mesmo conhecidos mortos. A possibilidade em si pode ser explicada pela natureza recente dessa rede social, que há pouco mais de dez anos passou a servir de ponto de encontro virtual, agenda digital e sala de bate-papo de milhões de pessoas em todo o mundo. Diante da finitude da vida e do aumento de usuários cadastrados, é previsível que cada vez mais pessoas partilhem, então, dessa possibilidade.

Entretanto, aparentemente distante de uma calculabilidade ou de uma operação racional sobre uma ordem estratégico-econômica, o fato é que muitos perfis continuam a ser visitados e "habitados" por estes visitantes, mesmo depois que o usuário responsável morre. São mensagens, memórias e desabafos destinados a pessoas que a rigor não mais possuem uma existência física, somente um endereço eletrônico identificado com fotos, textos e informações pessoais que configuram uma espécie de memorial digital e virtual. Trata-se, nesse sentido, de um comportamento bastante vinculado aos já tradicionais trabalhos de luto, onde as homenagens são prestadas também como forma de superar o abalo proveniente da perda de um ente querido e admirado.

Considerada por um lado um fracasso ou uma parada provisória da luta médica, subtraída por outro lado à experiência comum, chegando portanto ao limite do poder científico e escapando às práticas familiares, a morte é o outro lugar. Numa sociedade que só conhece oficialmente 'repouso' como inércia ou desperdício, ela é deixada, por exemplo, às linguagens religiosas fora de moda, entregue a ritos (...) o que se depõe em segredo ou ressurge mascarado é a morte que agora se tornou impensável e inominável (CERTEAU, 2011: 266)

Esse outro lugar não é somente onde jaz o morto, mas é também onde jaz a dificuldade em falar, em expressar, em concatenar as ideias, em reduzir o ruído que decorre do espanto diante da finitude. É, diante do caótico, tentar encontrar o cosmético, ou, de modo mais preciso, buscar um sentido para a desordem instaurada pela perda. Tentar fazer uma filtragem da emoção mediante o uso da razão - recorrer às palavras, ao jogo semântico e dinâmico da linguagem para interpretar, compreender, aceitar. Por isso, ao falar sobre esse inominável, a morte, Certeau diz que "o texto prolifera em torno dessa ferida" (CERTEAU, 2011: 98).

A mensagem de Camila $X$, deixada no perfil do usuário Jack $Z$ no dia de sua morte, em 11 de fevereiro de 2014, diz claramente: "Meu querido professor Jack Z, obrigado por fazer parte da minha formação profissional, sempre incentivando nossas ideias as vezes inusitadas e loucas! Sentirei saudades". O texto não se destina a "ninguém" ou "qualquer um", mas objetivamente ao professor Jack $Z$, que não vai ler e nem agradecer as palavras de sua antiga aluna. Em outro post, a mensagem de Jony $M$ é uma foto onde se vê um jovem Jack $Z$ com seu filho, o então pequeno Jony $M$, em uma praia, num momento familiar e descontraído. $A$ postagem recebeu mais de 100 curtidas, revelando um intuito velado de 
indiretamente "falar" com os demais familiares, amigos, conhecidos e admiradores do saudoso Jack $Z$.

Em outro perfil, no de Marcia $P$, as mensagens seguem um padrão semelhante, quer dizer, são direcionadas a quem não mais está presente. "Parabéns Marcia $P$, hoje porque você completaria seus tão sonhados 40 anos", registra a usuária Alexa $P$. São palavras que refletem a dor, a angústia, a saudade, que operam também como mecanismo de resignação, de aceitação dessa realidade imutável, num processo de superação. "Trata-se sobretudo de fazer passar a palavra, lá onde as palavras nos faltam" (DERRIDA, 2004: 16), como muito bem definiu Jacques Derrida por ocasião da morte de seu mestre, Emmanuel Lévinas. Um trabalho de luto que registra em palavras, que diz a quem não responde, que estrutura um discurso público em um perfil que somente será habitado por lembranças.

Por se tratar de uma ferramenta, um dispositivo de comunicação, o Facebook tem como princípio uma dinâmica na troca de mensagens entre seus usuários. É dessa característica que advém o sucesso dessa rede social, que articula diversas esferas da vida humana a procedimentos específicos de programação, tendo como pano de fundo a comunicação como fonte de dados, como produto final propriamente. Por isso, para que o dispositivo funcione plenamente, podemos dizer que são necessários no mínimo dois agentes, no caso usuários, que devem funcionar como polos dessa comunicação.

Enfim, o significado de comunicação também pode ser expresso na simples decomposição do termo comum + ação, de onde o significado 'ação em comum' (...) A 'ação' realizada não é sobre a matéria, mas sobre outrem, justamente aquela cuja intenção é realizar o ato de duas (ou mais) consciências com objeto comuns. (...) o termo 'comunicação' refere-se ao processo de compartilhar um mesmo objeto de consciência, ele exprime a relação entre consciências (HOHLFELDT; FRANÇA; MARTINO, 2001: 14-15)

Como, então, compartilhar um mesmo objeto de consciência em circunstâncias onde uma das consciências não está presente? De que modo realizar o clássico circuito emissor-receptor que faz circular as mensagens? A comunicação, como sabemos, é caracterizada pelo transporte de signos que permitem ao homem habitar o mundo em sua maneira mais própria, significando, valorando. Esse transporte, por sua vez, tem como destino outra consciência, o lugar onde essa significação continua operando e criando, portanto, as condições necessárias para essa "ação em comum", essa "relação entre consciências".

Em geral, quando isso não acontece ocorre o que poderíamos classificar de reflexão, no sentido de que o que é transportado (signos, significados etc.), apesar de registrados (publicados, postados, compartilhados) pelo usuário em um espaço, no caso, um perfil de um ente morto, se mostra somente como um reflexo, um retorno a si mesmo dessa consciência que ressente um outrem para poder ser comunicação. Como colocou o antropólogo José Carlos Rodrigues, "O falecido quase sempre deixar atrás de si um vazio interacional. É por esta lacuna que a morte se faz sentir" (RODRIGUES, 2013: 5-26). Ainda, também é possível inferir que tal atividade permite aos usuários estabelecer uma "comunicação indireta" com amigos, familiares e/ou conhecidos desse morto, ou seja, as mensagens deixadas no perfil são lidas e interpretadas por outros que não o destinatário original.

\section{Adeus virtual: tática na rede social}

Agora, portanto, já estamos em condições de começar a concluir. Partindo do princípio de que o Facebook é um dispositivo que visa a comunicação entre seus 
usuários, o uso de sua estrutura como forma de trabalho de luto, como espaço destinado de homenagens a usuários não mais ativos, parece configurar, em certa medida, a subversão de um uso inicial. Quer dizer, ao fazer de um serviço usado tradicionalmente como rede social, um lugar de uma prática ritual e de homenagem aos mortos, esse homem comum opera uma nova maneira de fazer dentro do campo imposto pelas estratégias de mercado estabelecidas por profissionais que calculam, ajustam, avaliam, aplicam e conduzem o produto de Mark Zuckerberg.

Poder-se-ia objetar, entretanto, que não se trata propriamente de uma tática, já que esse fazer não se apresenta mediante uma manipulação calculada, como nos casos de bricolagem e dos trabalhos com sucata. De qualquer modo, enquanto um comportamento que visa à superação de um estado, uma readaptação a uma nova realidade - a ausência de um ente falecido -, a prática pode, sim, ser comparada aos tais movimentos de peixes ou imemoriais inteligências. Uma conduta adotada pelos usuários como forma de preservar ou resgatar um equilíbrio ótimo, um estado ideal do organismo que sente, ressente e é refém de uma condição imposta de fora para dentro.

Ainda assim, sabemos que, no contexto da cultura de massas, a indústria cultural está sempre a estudar o cenário do ordinário, onde as produções independentes, os gostos e tendências antes não mapeadas, passam a integrar o horizonte de planejamento dos produtores, para, num momento seguinte, serem reconduzidas ao mercado como novas produções. Já vimos, inclusive, que o próprio negócio promove a retroalimentação entre as objetividades da empresa (articulação de conteúdo, disposição das informações, modos de navegação etc.) e as subjetividades de seus usuários (maneiras de usar, formas de produzir conteúdo em forma de dados mensuráveis etc.). Sobre isso, diz Morin:

Em determinado momento precisa-se de mais, precisa-se de invenção. É aqui que a produção não chega a abafar a criação, que a burocracia é obrigada a procurar a invenção, que o padrão se detém para ser aperfeiçoado pela originalidade (MORIN, 2011: 16)

${ }^{5}$ R7. Facebook vai transformar perfis de usuários mortos em memorial. Disponível em:

$<$ http://noticias.r7.com/tecnologia-eciencia/noticias/facebook-vaitransformar-perfis-de-usuarios-mortosem-memorial-20091027.html>

6 COMPUTERWORLD. Facebook expands user memorial page access. Disponível em:

<http://www.computerworld.com/articl e/2487993/social-media/facebookexpands-user-memorial-pageaccess.html>
Diante dessa perspectiva, retomando nosso caminho, podemos identificar uma mudança na política de manutenção de perfis de usuários mortos realizada pelo Facebook no final de $2009^{5}$, ano em que a empresa decidiu transformar estes perfis em memoriais. Mediante a solicitação de usuários previamente conectados ao falecido e a comprovação de sua morte, por meio do envio de atestado de óbito, por exemplo, as configurações do perfil em questão eram alteradas, dispostas de maneira diferente de um perfil ativo padrão, ficando visíveis somente aos usuários já conectados, isto é, não acessíveis ao público em geral.

Mais recentemente, em fevereiro de 2014, o Facebook fez uma revisão nessa política ${ }^{6}$ : passou a manter a exibição do memorial de acordo com as restrições de visibilidade dos usuários quando vivos. Ou seja, onde antes haveria um memorial fechado para terceiros, pode agora haver um aberto, dependendo apenas de o dono do perfil, quando em vida, estabelecer que suas publicações, fotos e demais informações são públicas, logo, podem ser vistas por todos, mesmo os não diretamente conectados. Segundo a empresa de Zuckerberger, a ideia seria balancear os desejos e o legado de seus usuários, respeitando a escolha inicial de cada um de deixar suas informações acessíveis ou não. Porém, suspeitamos que tal revisão busca principalmente ampliar a capacidade de produzir e levantar mais dados para o negócio.

Como colocado anteriormente, dentro da compreensão da mútua prospecção entre as produções da indústria cultural e das invenções dos homens comuns, 
7 Projeto de pequena empresa, formada por grupos de pessoas, com modelo de negócios, em geral, voltado para o mercado da Internet. Uma startup normalmente possui custo de manutenção muito baixo e capacidade de rápido crescimento.

${ }^{8}$ Disponível em: <http://eterni.me/>

9 Forma de cultura onde as novas tecnologias de comunicação e informação têm papel fundamental. podemos perceber uma relação, um diálogo não de todo amistoso como numa conversa de bar, estabelecido entre essas diferentes esferas - ou, para utilizar uma metáfora de Heráclito de Éfeso, uma "harmonia de tensões contrárias, como de arco e lira" (HERÁCLITO, 2005: 93). Dentro desse contexto, as produções da indústria criam oportunidades, estimulam a criatividade dos "fracos", artistas, artesãos e empreendedores, que manipulam as peças e a ordem impostas, criando artes, poesias, produções independentes. Esse "uso tático", entretanto, seria então capturado, já na sequência, pela estratégia dos "fortes", e assim sucessivamente.

A startup ${ }^{7}$ Eterni.Me é outro exemplo desse intenso jogo de criação em meio a oportunidades. Ainda em fase de construção, o serviço é fruto do empreendedorismo e da criatividade dos colegas Marcius Ursache, Nicolas Lee e Rida Benjelloun, que pretendem "imortalizar" seus clientes através da simulação dos mesmos. De modo simplificado, o Eterni.Me funciona da seguinte maneira: a) o cliente contrata o serviço, em que uma equipe especializada faz o levantamento de todo o seu rastro digital (comentários, fotos, navegação etc.); b) cria um avatar do contratante com base em fotos e vídeos enviados pelo mesmo; c) modula uma série de diálogos utilizando algoritmos que analisam prováveis respostas a possíveis perguntas, seguindo a indicação do levantamento prévio do segundo tópico; d) por fim, simula a voz do cliente tendo por referência arquivos de áudio enviados pelo cliente. Voilà: o morto agora pode conversar.

Se a proposta do Eterni.Me parece ser um tanto quanto estranha, o resultado poderá ser ainda mais. "Nós todos passaremos mais cedo ou mais tarde, deixando apenas algumas memórias para trás, para a família, amigos e da humanidade. E, eventualmente, todos nós somos esquecidos" ${ }^{8}$, é o texto que aparece no topo da primeira página do site. Segue a pergunta: "Mas e se você pudesse ser lembrado para sempre?". No centro da página, resumindo o futuro empreendimento, em letras garrafais, pode-se ler: "Simplesmente torne-se imortal". Um projeto, de fato curioso, que começa a ser fomentado por usuários que operam segundo as regras da programação e empreendem sua produção segundo a lei dos negócios.

Tanto no caso dos memoriais do Facebook, quanto no caso do Eterni.Me, vemos aspectos usos, práticas, táticas sendo utilizadas de maneiras diferentes por usuários: uns apenas reagindo à angústia gerada em decorrência do confronto com a morte; outros utilizando a razão para erigir um negócio que tem como objeto a morte alheia. Em ambos os cenários parece ser a aceitação da finitude do outro e de si próprio que norteia de maneira velada o comportamento dos usuários. A comunicação, o exercício da escrita, a capacidade de verbalizar as emoções e os sentimentos direcionam-se ao morto, não na esperança de que haja uma resposta deste - no exemplo do Eterni.Me, assumimos que os usuários sabem se tratar de uma simulação. Ao contrário, a expectativa é a de que se complete o trabalho de luto com a aceitação da morte, com a resignação na ausência do ente e com a percepção da finitude de tudo e de todos.

Numa realidade onde a cibercultura ${ }^{9}$ encontra-se imersa e diluída nas práticas humanas, no cotidiano de famílias e grupos sociais, onde as relações entre as pessoas e as instituições são cada vez mais são deslocadas para um contexto digital e virtual, alguns paradigmas são colocados em questão - a difusão da informação, a produção de conhecimento, a participação política, a interação social. Outros, porém, permanecem inalterados, como é o caso da morte, questão do sujeito (CERTEAU, 2011: 266), que apesar de inominável é destino inegável de todo ser vivo - "Toda relação com o outro seria, antes e depois de tudo, um adeus" (DERRIDA, 2004: 15). 
${ }^{10}$ Ainda que saibamos de casos onde o "falecido" encomenda mensagens para familiares e amigos em datas estabelecidas antes de sua morte.
Entretanto, se a morte é inevitável, a maneira de lidar com ela também sofre uma adaptação. $O$ ente agora morto deixa para trás um memorial que, ao imortalizar uma dimensão de seu legado, uma fração de sua vida, faz do tempo um aliado. Permite um "acesso", via um dispositivo digital, àquele sobre quem se fala, se destina as homenagens, mas que não mais está presente para responder. Se a vida é finitude, a tecnologia permite reconstruir o mundo e o recolocar no virtual, onde o tempo se torna infinito.

De quem partiu não haverá notícias, não haverá novo post, não haverá fotos, dizeres ou mesmo a tão sonhada despedida, um "até logo" providencial ${ }^{10}$. De quem partiu restará apenas um perfil-memorial, por onde alguns passarão deixando mensagens, compartilhando suas dores, alegrias, prestando suas homenagens, definindo suas respectivas saudades. Uma produção quase que silenciosa de dizeres que refletem e se fazem refletir no diálogo, quase sempre mudo, de quem apenas observa o tartamudear de uma procissão, de um rito diferente.

\section{Referências bibliográficas}

AGAMBEN, G. O que é contemporâneo?. Chapecó: Argos, 2009.

CERTEAU, M. A invenção do cotidiano 1: Artes de fazer. Petrópolis: Vozes, 2011.

DELEUZE, G. Conversações. São Paulo: Editora 34, 2010.

DERRIDA, J. Adeus a Emmanuel Lévinas. São Paulo: Perspectiva, 2004.

FELINTO, E. A religião das máquinas: Ensaios sobre o imaginário da cibercultura. Porto Alegre: Sulina, 2005.

HEIDEGGER, M. Nietzsche - volume I. Rio de Janeiro: Forense Universitária, 2007.

HERÁCLITO. Fragmentos (Coleção Os Pensadores). São Paulo: Nova Cultural, 2005.

MACHADO, J. O que pesquisar quer dizer? - Como fazer textos acadêmicos sem medo da ABNT e da CAPES. Porto Alegre: Sulina, 2010.

MORIN, E. Cultura de massas no século XX - volume 1: neurose. Rio de Janeiro: Forense Universitária, 2011.

RECUERO, R. Redes sociais na internet. Porto Alegre: Sulina, 2011.

RODRIGUES, J. C. Publicidade, silêncio, personalização, espetáculo: representações da morte no Ocidente. Revista ALCEU. Rio de Janeiro, v. 13, n. 26. p. 5-26.

SODRÉ, M. Antropológica do espelho: Uma teoria da comunicação linear e em rede. Petrópolis: Vozes, 2002.

. A televisão é uma forma de vida. Revista FAMECOS. Porto Alegre, $\mathrm{n}$. 